\title{
SEA LEVEL RISE IMPACT ASSESSMENT AND MITIGATION ALTERNATIVES DEVELOPMENT FOR BALBOA ISLANDS, CITY OF NEWPORT BEACH, CALIFORNIA
}

\author{
Ying Poon ${ }^{1}$, Brett Sanders ${ }^{2}$, Randy Mason $^{3}$ and Robert Stein ${ }^{4}$
}

\begin{abstract}
The City of Newport Beach (City), a highly developed, densely populated coastal city in southern California is periodically subject to flooding from coincident high tides and waves. To prepare for sea level rise and potential flood damages, the City initiated a study to assess the potential flood impact to Balboa Island and Little Balboa Island. A 2D flood simulation model is utilized to investigate the effect of high tides occurring with increased sea levels, and a simple wave overtopping model is proposed to account for the effect of wind waves and ocean swells. The results of the flood model simulations were used to help the City to formulate flood inundation mitigation alternatives.
\end{abstract}

Keywords: Sea Level Rise, Coastal flooding, Flood mapping, Inundation modeling, Wave overtopping

\section{INTRODUCTION}

The City of Newport Beach (City) has been dealing with localized flooding for several decades due to lower-than-optimum seawall and land mass heights in various locations around Newport Harbor. Flooding of streets and walkways has occurred on Balboa Peninsula, Balboa Island and other localized areas as a consequence of high tides and waves. The challenge of flood control is compounded by City storm drain lines that empty by gravity into the Bay and therefore do not provide flood relief when the bay water level is high. To a lesser extent, distress in the form of concrete cracks and construction joints allows water to breach the protection of these walls and contribute to localize flooding.

To prepare for sea level rise and potential flood damages, the City of Newport Beach

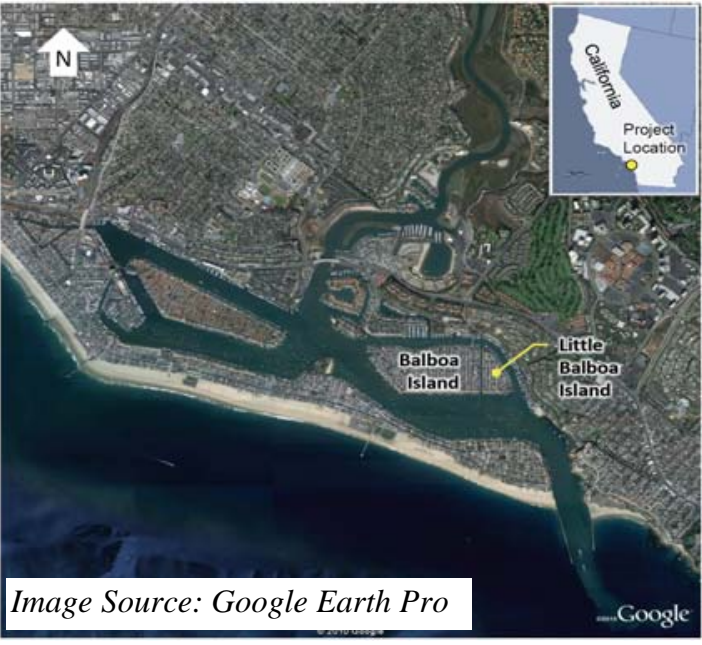

Figure 1. Site Location initiated a study to assess the potential flood impact to Balboa Island and Little Balboa Island. The study includes: 1) evaluation of conditions of existing seawalls protecting the islands, 2) prediction of flood water overtopping and resulting inundation due to sea level rise and storm events over the next 100 years, and 3) evaluation of flood hazard mitigation alternatives.

\section{BALBOA ISLAND AND LITTLE BALBOA ISLAND}

Balboa Island and Little Balboa Island are two adjacent islands located in Lower Newport Bay in the City of Newport Beach in Orange County, California (Figure 1). These two islands are also collectively known as the Balboa Islands. Both islands are encircled by concrete seawalls that provide protection from flooding during periods of high tides and waves. Under present-day conditions, wave overtopping and flooding do occasionally occur on Balboa Island during high tide and high wave events, but in general do not cause damage to residences, businesses, vehicles or public infrastructure. The higher seawalls around Little Balboa Island protect it from seawater overtopping.

During high water events, the City closes the storm drain outlets to the Bay to prevent sea water from flowing backwards through the storm water outlets and inundating Balboa Island. Figure 2

\footnotetext{
${ }^{1}$ Everest International Consultants, Inc., 444 West Ocean Blvd., Suite 1104, Long Beach, CA 90802, U.S.A.

${ }^{2}$ Civil and Environmental Engineering, University of California, Irvine, Irvine CA 92697, U.S.A.

${ }^{3}$ URS Corporation, 310 Golden Shore, Suite 100, Long Beach, CA 90802, U.S.A.

${ }^{4}$ City of Newport Beach, 3300 Newport Blvd., Newport Beach, CA 92663
} 
shows a picture of City personnel pumping out water that was collected at the storm drain outlet junction structure located at a bay-front street in a high water, high wave event in December 22, 2010.

During high water and high wave events, there are four areas on Balboa Island that are particularly susceptible to flooding; they are: the Balboa Island ferry boat landing and its surroundings, and the three bridges on the Island - the Marine Avenue Bridge, the Park Avenue Bridge, and the Collins Island Bridge. If an extension or reconstruction of the existing seawall is to be performed, these four areas need to be modified to prevent them from acting as openings in an otherwise solid seawall fortification around the island. Figure 3 shows flooding of the Balboa Island ferry landing area during the December 22, 2010 flood event.

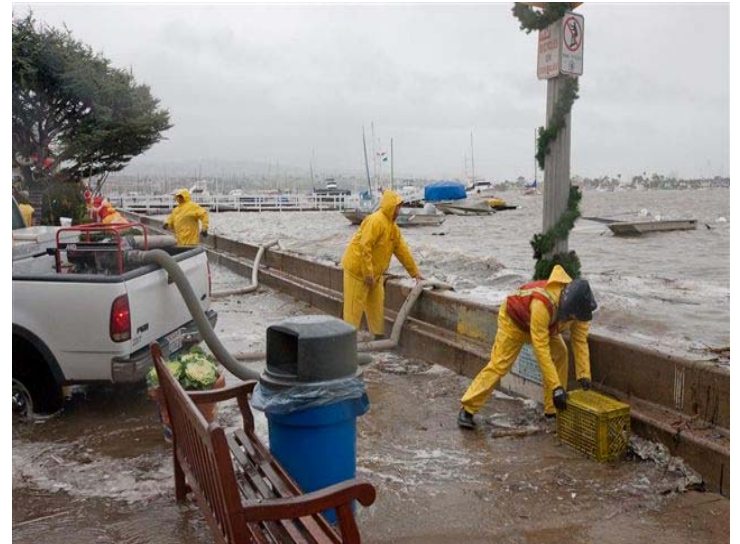

Figure 2. City personnel pumping storm water

\section{FLOOD MODELING}

An unstructured, variable grid, Godunovtype finite volume model, based on the shallow water equations, BreZo, was applied to Newport Harbor to map present-day (2010) and future flood zones on Balboa Island and Little Balboa Island. The model incorporated scenarios for sea level rise projected for 2025 , 2050 and 2100, as well as proposed improvements. The model was developed to account for both wave- and tide-driven sea wall overtopping. Moreover, overtopping flows are predicted to spread in accordance with local topography and the effects of gravity and friction. Detailed descriptions of the Brezo model used for this study can be found in Sanders (2008) and Schubert et. al. (2008).

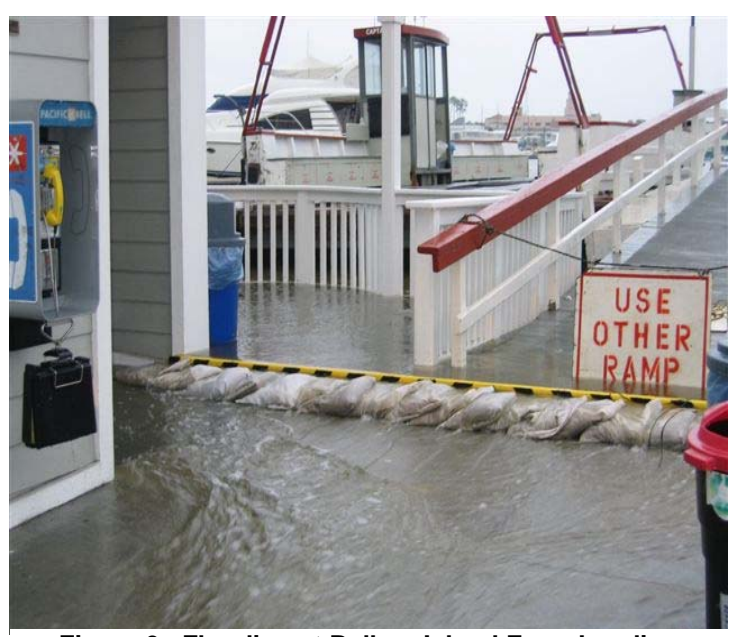

Figure 3. Flooding at Balboa Island Ferry Landing

A variable-resolution computational mesh was developed for this study. In preparing the mesh, special attention was paid to Balboa and Little Balboa islands. Edges of the mesh were aligned with sea walls around these islands, and flagged with unique identifiers that allowed the model to easily incorporate surveyed wall height data and the wave-driven overtopping data. The mesh was locally refined on Balboa and Little Balboa islands for flood mapping precision, an intermediate resolution was used within the embayment, and a coarser resolution was used offshore. The finest and coarsest resolution corresponds to approximately 10 feet and 1000 feet, respectively. In total, the mesh consisted of 282,935 cells.

Several datasets were relied upon to implement BreZo, including topographic and bathymetric data, seawall and house first-flood elevation data, ocean tide height data (including sea level rise projections), and wave-driven overtopping rates. These are briefly described in the following. 


\section{Topographic and Bathymetric Data}

Several sources of data were obtained and organized to provide a seamless terrain map that synthesizes available topographic (above sea level) and bathymetric (below sea level) ground elevation data in the vicinity of Newport Harbor. The data sources include the following:

1. Light Detection and Ranging (LiDAR) topography data;

2. Upper Bay bathymetry resulting from a multi-beam survey for the U.S. Army Corps of Engineers, Los Angeles District;

3. Lower Bay bathymetry data resulting from a multi-beam survey for the U.S. Army Corps of Engineers, Los Angeles District; and

4. Offshore bathymetry data from the National Geophysical Data Center (NGDC) 3 Arc-Second Coastal Relief Model accessed from the Southern California Coastal Ocean Observing System (SCCOOS) website.

\section{Seawall Elevation and House First Floor Elevation Data}

Balboa and Little Balboa Islands are encircled by concrete seawalls that provide protection from flooding during periods of high tides and waves. Because elevations of the seawall represent a threshold for overtopping, it is critically important that they are surveyed with 0.1 foot accuracy or less. The seawall elevations used for setting up the BreZo Model were surveyed for this study with a vertical accuracy of approximately 0.01 feet

Ninety-one houses along three streets were also surveyed for their first-floor elevations. The data were used to generate a probability distribution representing the first floor elevations for the Balboa Islands which are used for assessing potential flood impacts to the houses on the Islands under different flood model scenarios.

\section{Water Level Description}

Extreme high tide scenarios are needed to support hydraulic modeling of coastal flooding and plan for sea level rise. The hydraulic model uses Equation 1 below to simulate the rise and fall of the ocean height, $\mathrm{h}(\mathrm{t})$, which in turn causes the tide to rise in the embayment and potentially flood low lying areas.

$$
h(t)=H_{0}+a \cos \left(\frac{2 \pi\left(t-t_{1}\right)}{t_{2}}\right)+b \operatorname{sech}^{2}\left(\frac{t-t_{3}}{t_{4}}\right)
$$

In this equation, $\mathrm{t}$ represents time, $\mathrm{H}_{0}$ represents the mean sea level, a represents the amplitude of a periodic wave with phase $t_{1}$ and period $t_{2}$, and $b$ represents the amplitude of a solitary wave with phase $t_{3}$ and duration parameter $t_{4}$. Equation 1 allows the hydraulic model to account for increases in sea level and the probability of an extreme high tide. The value of HO is varied by year to account for higher sea levels projected for the future. The remaining tide-height parameters $(a, b$, and time constants) are specified to simulate either a 10 percent or 1 percent annual exceedance probability tide. Two sources of information were merged to parameterize Equation.1: hourly tide measurements and sea level rise projection.

Over 80 years of hourly tide measurements at Los Angeles (NOAA Station ID: 9410660) were analyzed for this study. Using the hourly record, the mean and maximum value of the tide height from each year was computed, and a linear model was least-squares fit to each of the time series. These tide heights and trends are shown in Figure 4. 


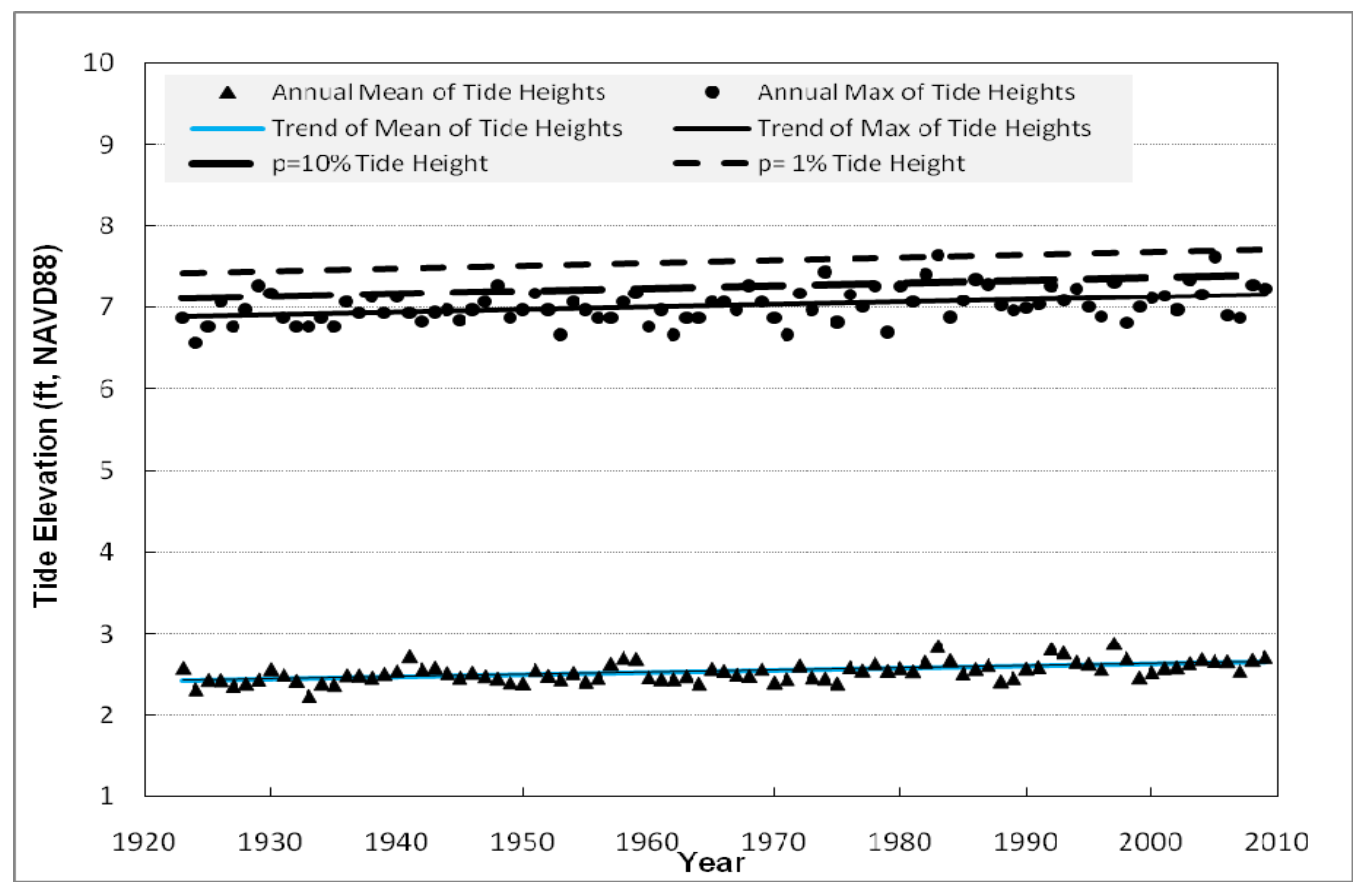

Figure 4. Mean and annual maximum tide elevations, and trends of mean, maximum, $10 \%$ and $1 \%$ annual exceedance-probability tide heights, Los Angeles, 1923 - 2009

As shown in the Figure, the maximum tide heights exhibit considerable inter-annual variability on the order of one foot. For this study, this variability is treated by considering the extreme tide height to be a random variable and probability analysis was performed to obtain the $1 \%$ and $10 \%$ extreme high tide trends shown in the figure. Based on the analyses of the historical data, mean sea level for 2010 is 2.65 feet NAVD88, and the $10 \%$ and 1\% probability of occurrence extreme tide heights for 2010 are 7.41 and 7.71 feet NAVD88, respectively.

Future mean sea levels are estimated by applying the methodology recommended by the U.S. Army Corps of Engineers (USACE 2009). This gives sea level rise, SLR (in feet), between years $\mathrm{y}_{1}$ and $\mathrm{y}_{2}$ as follows,

$$
\operatorname{SLR}\left(y_{1}, y_{2}\right)=0.0056\left(y_{2}-y_{1}\right)+3.2964 \times 10^{-4}\left(\left(y_{2}-1986\right)^{2}-\left(y_{1}-1986\right)^{2}\right)
$$

Figure 5 show projections of future tide heights based on the sea level rise trends given by Eq. 2, assuming the trend for extreme high tide follows the trend for mean sea level. Projections point to a rapid increase of sea level over the next decade, compared to the historical rate of rise. The projections also show that the differences between $10 \%$ and $1 \%$ extreme tide events is very important in the near term, but less important in the long term compared to sea level rise. 


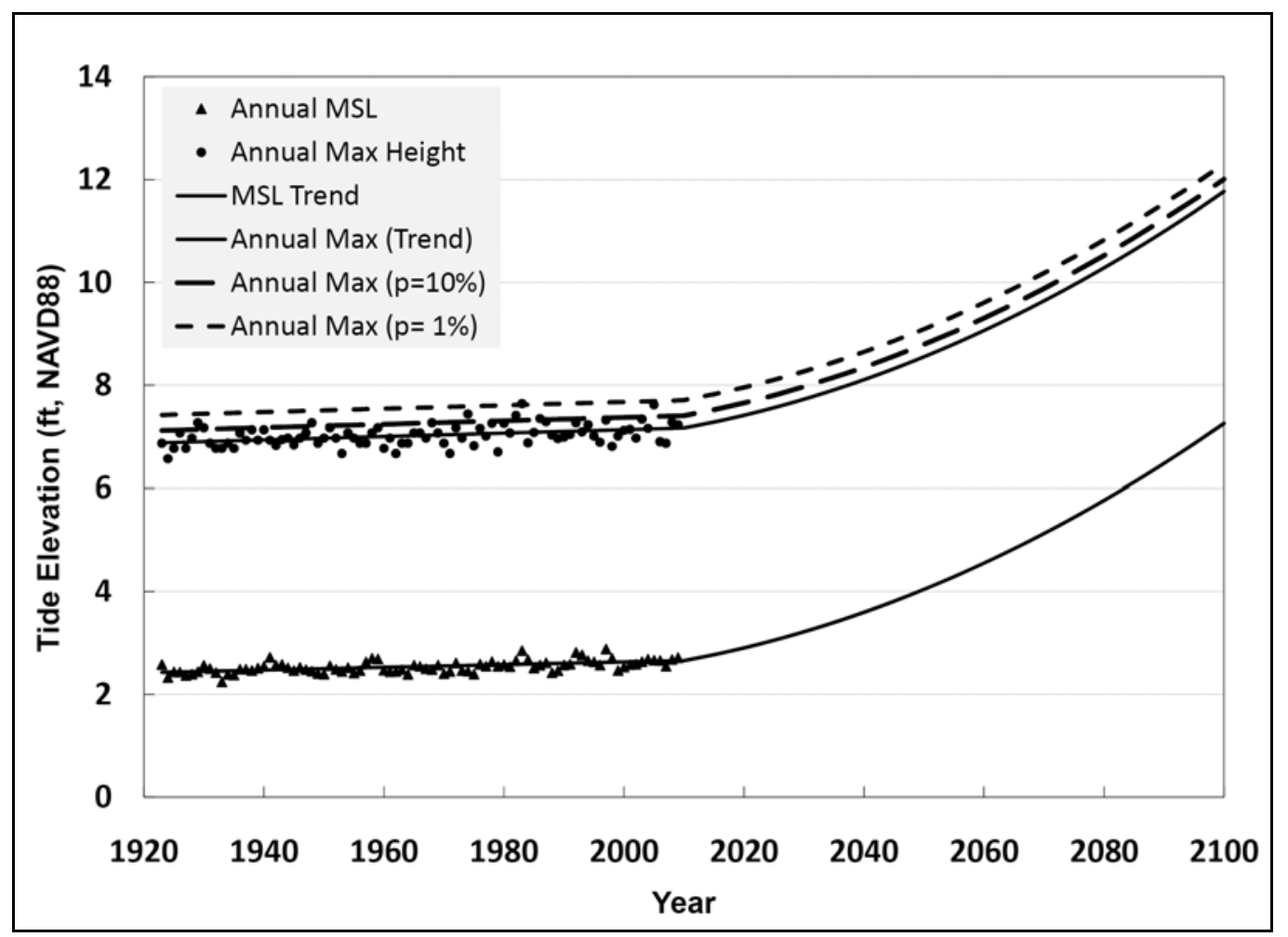

Figure 5. Projections of mean sea level and extreme tide heights through Year 2100

\section{Wave-driven Overtopping Rates}

Waves are an important driver of embayment flooding when the tide level approaches the crest of a flood barrier. Wave action provides the necessary energy for water to rise up above the tide level and spill over the barrier. The rate at which this occurs is dependent on many factors such as the wave height, period, water depth at the toe of the wall, the height of the tide, and the height of the wall. Figure 6 shows an example of wave overtopping a seawall at Balboa Island during the December 22, 2010 flood event.

It can be expected that as the tide height, $h$, rises, the rate of wave

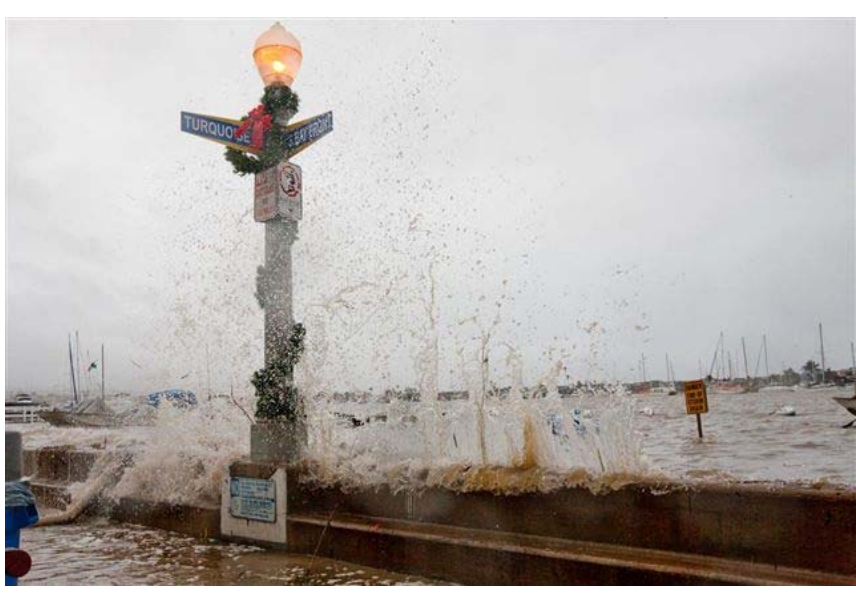

Figure 6. Waves Splashing over the Balboa Island Seawall (December 22, 2010)

overtopping will commence once the tide reaches a height that allows the first drops of water to spill over the wall. As the tide continues to rise, the rate of overtopping can be expected to increase until the tide height surpasses the height of the wall. Thereafter, weir-like flow can be expected to dominate the overtopping rate and wave-driven flow can be ignored. BreZo was modified to account for the mode of 
wave overtopping described here. The following formula was used to specify the volumetric flow rate along sea walls where wave overtopping is expected:

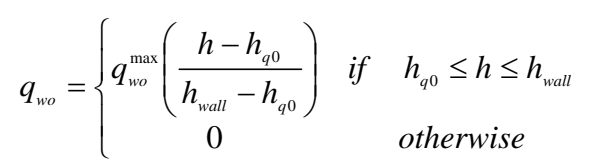

where $q_{w o}^{\max }$ represents the maximum rate of wave overtopping based on all possible water levels, hwall represents the height of the wall, and hq0 represents the tide height corresponding to the onset of overtopping.

Wave overtopping rates were calculated using the ACES program within the CEDAS (version 4.03) suite of programs developed by the U.S. Army Corps of Engineers (Veri-Tech, Inc., 2009). The parameters controlling the onset of wave overtopping and the overtopping rate include structure type and structural slope, beach slope, water depth, and wave characteristics (height and period). Based on the wall types, mudline elevations, and wave conditions for Balboa Island, wave overtoppings were calculated for three different reaches. Reach 1 and 2 correspond to the southwest and south sides of Balboa Island, respectively, and Reach 3 corresponds to the south side of Little Balboa Island. All other sides of these islands were ignored, relative to wave overtopping, due to a negligible wind fetch.

\section{MODEL SCENARIOS AND RESULTS}

The model was used to compare flood zones based on present-day seawall heights, a future sea wall raised uniformly to a 9.8 feet NAVD88 height, and an interim extension of the sea wall height by 6 to 8 inches (replacing existing seawall cap with a taller cap, add an extension to the existing cap, or deployment of sandbags). A total of 17 different modeling scenarios were considered to account for the varied effects of high tides, waves, sea levels, and sea wall heights. These model scenarios and model results are shown in Table 1 . In the table, the number of flood impacted buildings for each model scenario is estimated by comparing the modeled flood water depth at each parcel with a randomly generated first floor elevation for that parcel based on the first floor probability distribution described earlier.

The model results show that Balboa Island is presently vulnerable to extensive flooding because of low points in the seawall at the Balboa Ferry ramp, the Collins Island bridge crossing, and the relatively low height of its seawall. The sea wall around Little Balboa Island is higher than the Balboa Island sea wall and therefore offers better protection against present-day flood risks. Modeling shows that present-day flooding may occur from a combination of high tides and high waves, and the southwest boundary of the island is particularly vulnerable to overtopping due to its exposure to southerly and westerly winds. Modeling also shows that a combination of high tides and ocean swell may cause overtopping of the southern seawall due to its orientation towards the harbor mouth. Figure 7 shows an example of flood model results for the existing seawalls with and without the effects of wave overtopping under a 10\% exceedance tide (Scenario 1 versus Scenario 3).

Modeling also shows that by extending the existing seawall cap by 6 inches and raising the height of the Balboa ferry ramp and Collins Island bridge crossing to the height of adjoining sea walls, both islands would be protected through 2025 from a flood event caused by the combined effects a $1 \%$ exceedance probability storm tide and $10 \%$ exceedance probability wind waves. However, the islands would not be protected far past 2025 based on current sea level rise projections. The effectiveness of extending the existing seawall cap by 6 inches is illustrated in Figure 8, which compares the flood model results for Scenario 7 (existing seawall, year 2025, 1\% exceedance tide and wind waves) with Scenario 12 (same environmental condition as Scenario 7 but with 6 inch extension of seawall).

Modeling also shows that a seawall constructed to a height of $9.8 \mathrm{ft}$ NAVD88, uniformly around the islands including all road crossings, would provide protection from flooding from the $1 \%$ storm 
tide and $10 \%$ waves scenario through 2050. The islands' seawalls would need to be raised 3 or 4 feet to protect the islands after 2050, based on current sea level rise projections.

Table 1. Model Results for 17 Scenarios

\begin{tabular}{|c|c|c|c|c|c|c|c|c|}
\hline 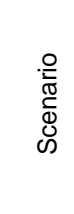 & 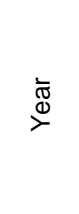 & 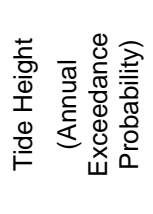 & 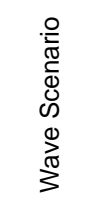 & 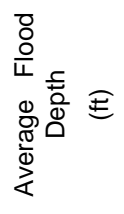 & 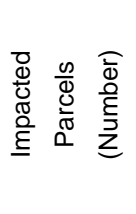 & $\begin{array}{l}\bar{d} \\
\frac{d}{0} \\
\frac{\pi}{2} \\
\frac{\text { E}}{0} \\
\frac{0}{0} \\
\frac{0}{0} \\
\frac{\pi}{0}\end{array}$ & 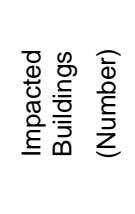 & 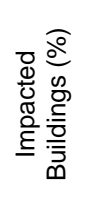 \\
\hline \multicolumn{9}{|c|}{ Existing Condition Scenarios } \\
\hline 1 & 2010 & $10 \%$ & $\begin{array}{c}\text { No } \\
\text { Waves }\end{array}$ & 0.26 & 61 & 4.0 & $3 \pm 2$ & 0.2 \\
\hline 2 & 2010 & $10 \%$ & $\begin{array}{c}\text { Wind } \\
\text { Waves }\end{array}$ & 0.26 & 61 & 4.3 & $3 \pm 2$ & 0.2 \\
\hline 3 & 2010 & $10 \%$ & $\begin{array}{c}\text { Ocean } \\
\text { Swell }\end{array}$ & 0.29 & 514 & 36.5 & $24 \pm 5$ & 1.7 \\
\hline 4 & 2010 & $1 \%$ & $\begin{array}{c}\text { Wind } \\
\text { Waves }\end{array}$ & 0.36 & 324 & 23.0 & $22 \pm 4$ & 1.5 \\
\hline 5 & 2025 & $10 \%$ & $\begin{array}{c}\text { Wind } \\
\text { Waves }\end{array}$ & 0.48 & 681 & 48.3 & $66 \pm 7$ & 4.7 \\
\hline 6 & 2025 & $10 \%$ & $\begin{array}{l}\text { Ocean } \\
\text { Swell }\end{array}$ & 0.79 & 1,176 & 83.4 & $235 \pm 13$ & 16.6 \\
\hline 7 & 2025 & $1 \%$ & $\begin{array}{c}\text { Wind } \\
\text { Waves }\end{array}$ & 1.16 & 1,179 & 83.6 & $420 \pm 14$ & 29.8 \\
\hline 8 & 2050 & $10 \%$ & $\begin{array}{c}\text { No } \\
\text { Waves }\end{array}$ & 1.84 & 1,410 & 100.0 & $894 \pm 17$ & 63.4 \\
\hline 9 & 2050 & $1 \%$ & $\begin{array}{c}\text { No } \\
\text { Waves }\end{array}$ & 2.15 & 1,410 & 100.0 & $1047 \pm 15$ & 74.3 \\
\hline 10 & 2100 & $10 \%$ & $\begin{array}{c}\text { No } \\
\text { Waves }\end{array}$ & 5.02 & 1,410 & 100.0 & $1410 \pm 1$ & 100.0 \\
\hline \multicolumn{9}{|c|}{ 6-inch Extension Scenarios } \\
\hline 11 & 2010 & $1 \%$ & $\begin{array}{c}\text { Wind } \\
\text { Waves }\end{array}$ & 0.03 & 0 & 0.0 & 0 & 0.0 \\
\hline 12 & 2025 & $1 \%$ & $\begin{array}{c}\text { Wind } \\
\text { Waves }\end{array}$ & 0.12 & 12 & 0.9 & $0-1$ & $<0.1$ \\
\hline \multicolumn{9}{|c|}{ 10-foot Seawall Scenarios } \\
\hline 13 & 2010 & $1 \%$ & $\begin{array}{c}\text { Wind } \\
\text { Waves }\end{array}$ & 0 & 0 & 0.0 & 0 & 0.0 \\
\hline 14 & 2025 & $1 \%$ & $\begin{array}{c}\text { Wind } \\
\text { Waves }\end{array}$ & 0 & 0 & 0.0 & 0 & 0.0 \\
\hline 15 & 2050 & $1 \%$ & $\begin{array}{c}\text { Wind } \\
\text { Waves }\end{array}$ & 0 & 0 & 0.0 & 0 & 0.0 \\
\hline 16 & 2050 & $10 \%$ & $\begin{array}{c}\text { Wind } \\
\text { Waves }\end{array}$ & 0 & 0 & 0.0 & 0 & 0.0 \\
\hline 17 & 2100 & $1 \%$ & $\begin{array}{c}\text { Wind } \\
\text { Waves }\end{array}$ & 5.30 & 1,410 & 100.0 & $1410 \pm 1$ & 100.0 \\
\hline
\end{tabular}



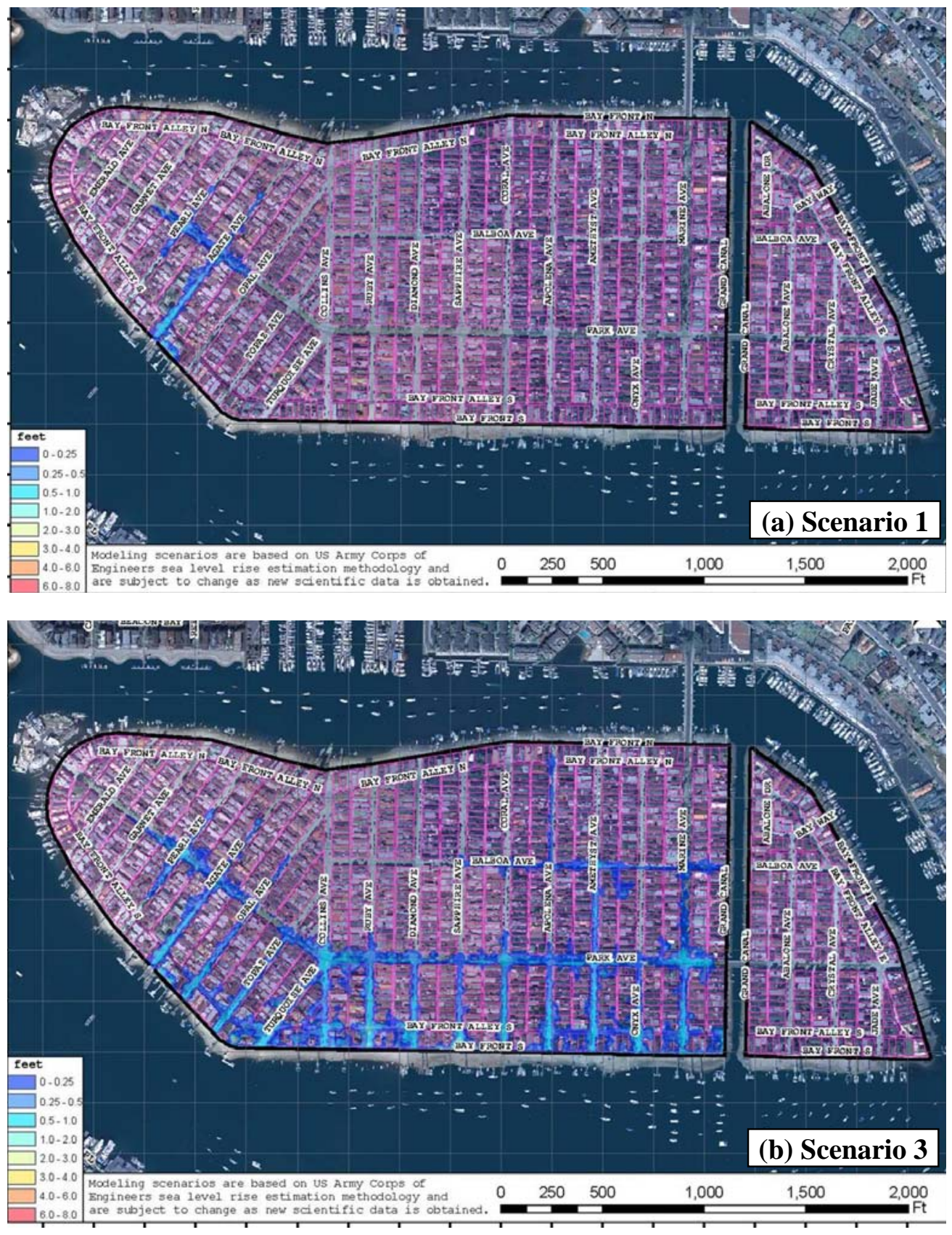

Figure 7. Modeled flood depths for existing condition

(a) Scenario 1 - without waves; and (b) Scenario 3 - with waves 

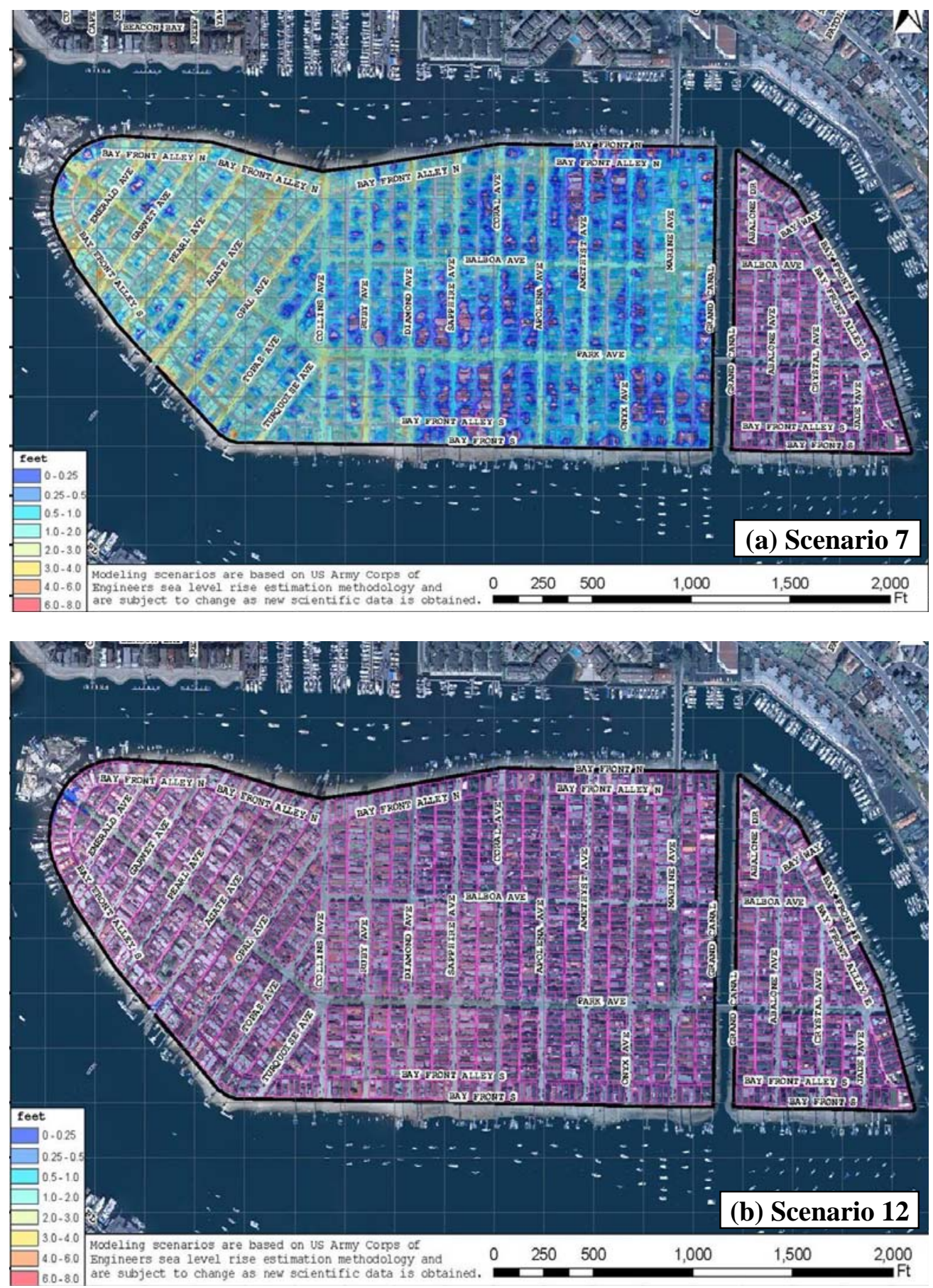

Figure 8. Modeled Year 2025 flood depths for $1 \%$ exceedance tide and wind waves (a) Scenario 7 - existing ] seawall and (b) Scenario 12 - 6-inch extension

\section{FLOOD INUNDATION MITIGATION SOLUTIONS}

Review of available documents, reports and drawings revealed that most of the existing concrete seawalls were constructed in the 1930s to replace earlier timber seawalls. Site observations determined that an undocumented extension of 6 to 12 inches was added to the seawall cap around Little Balboa 
Island. The site observations also found universal distress in the caps, specifically multiple cracks, coinciding with the locations of the soldier piles. In addition, common and continuous cracks were observed along the seawall approximately 2- to 4-inches above the boardwalk behind the seawalls. Based on the review of construction documents, assessment of the construction practices in the 1930s, and site observations of the existing seawall conditions, it is estimated that the remaining useful life of the seawalls is between 10 to 25 years.

Even though it is possible to either replace the existing cap with a taller cap or extend the existing cap to a taller height to prevent flooding from high water levels and wave overtopping, it is not recommended because the existing seawalls at Balboa Island and Little Balboa Island only have a remaining usable life of between 10 to 25 years. In addition, the flood modeling results indicate that properly maintained sandbag extension would be sufficient to prevent overtopping from high tides and waves for the remaining usable life of the seawalls. Hence, instead of fixing the cap, a replacement seawall with top elevation at +9.8 feet NAVD88 is recommended. The new seawall should have a flexible design such that it can easily be further extended by 3- to 4-feet if and when rising sea level dictates. For the Balboa ferry terminal, solutions include either raising the dock and launch ramp, or shifting the launch ramp further into the main channel so that existing properties can remain unchanged. Finally, to limit future damages, the City should establish appropriate minimum lowest first floor elevation in accordance with the federal Base Flood Elevation (BFE).

\section{REFERENCES}

Sanders, B.F. (2008) Integration of a shallow-water model with a local time step, Journal of Hydraulic Research, 46(4) 466-475.

Schubert, J.E., Sanders, B.F. Smith, M.J. and Wright N.G. (2008) Unstructured mesh generation and landcover-based resistance for hydrodynamic modeling of urban flooding, Advances in Water Resources, doi:10.1016/j.advwatres.2008.07.012.

U.S. Army Corps of Engineers. 2009. Water Resources Policies and Authorities Incorporating SeaLevel Change Considerations in Civil Works Programs.

Veri-Tech, Inc. 2009. Coastal Engineering Design and Analysis System (CEDAS) 4.03. http://www.veritechnic.com/products/cedas/index.php. 